\title{
ADDRESS TERMS ACROSS CULTURES: A SOCIOPRAGMATIC ANALYSIS
}

\author{
Surono \\ Universitas Ahmad Dahlan \\ Yogyakarta, Indonesia \\ surono@pbi.uad.ac.id
}

\begin{abstract}
In daily communication, the use of address terms is very common and natural to communicants. They are required to use the terms appropriately in terms of some aspects and points of view. The wrong use of the terms may disturb the social relationship among the communicants. Address terms can be used among members of a family and by people publicly. Address terms can also be used variously by the people coming from different cultures. In this study, sociopragmatic approach was used in which the characteristics of the users of address terms were considered. In this descriptive qualitative analysis, the culture in terms of which the address terms were used was Javanese culture with some subcultures. In English and Indonesian cultures, the address terms were analyzed as a comparison with Javanese culture. The data were the expressions containing address terms in Javanese, Indonesian, and English. The data of Javanese and Indonesian address terms were collected from the daily life and those of English were collected from written and electronic sources. The data were collected by using observation method, noting technique, and intuition technique. The data were analyzed by using padan pragmatik method, comparison method, and agih method for certain cases. The findings show that there are a lot of address terms which are used very variously in Javanese, Indonesian, and English cultures. Regarding the characteristics of the address terms users, in family life, there are many specific address terms, while in public life, there are many generic address terms. In certain cases, there is no a clear cut of the use of the address terms in family life and in public life. Some address terms are used both in family life and in public life. Address terms are also used formally and informally. Among the factors influencing the use of the address terms are (1) different kinship, (2) age, (3) education, (4) (Islam) religion knowledge, (5) sex, (6) different job accupation/position, (7) different intimacy, (8) social class, and (9) the geographical group.
\end{abstract}

Key words: address terms, cultures, influencing factors, family life, public life

\section{INTRODUCTION}

Addressing is an important activity for humans as social creatures all over the world. In the environments of family, society, workplace, etc. they cannot be separated from addressing activities either in the beginning, in the middle, or at the end of meeting with others. They use address terms to address the interlocutors or the third persons. Just because of misusing the address terms, two parties may misunderstand and get a problem (see Wierzbicka,
2003:64). Yang (2010) explains that "forms of address are important for effective and successful communication and have long been considered a very salient indicator of status of social relationships. One can use different forms of address to show his respects or fondness of other people, or to insult or depreciate them". A system of address terms is a part of indispensible communication. Different countries or cultures show different address terms that seem to be complicated because in one culture, even subculture, there can be many choices of address terms that must be used. Javanese, Indonesian, and English cultures show different complexities in the system of address terms. This is in line with what $\mathrm{Yu}$ and Ren (2013:35) say. They explain that every culture or society has its own rules or norms governing the choice of address terms that are appropriate and cultural specific for use between the people involved in the verbal interaction. The larger the cultural differences are, the larger the differences in address terms will be. Thus, as an important part of language, address terms are influenced by and reflect cultures in which they are used.

Address terms are the terms in the forms of words, phrases, names, titles or the combination of them which are used to address the interlocutors or other persons (Wardhaugh, 1992: 265). Address terms are used by the speaker to, among others, respect other people, show familiarity or unfamiliarity, show intimacy, and show social status. These functions can be seen from the forms and the users of the address terms. The individual forms of address terms can indicate the social background of the speakers. Contrastively, the social relationship between the speakers leads to the use of different address terms.

A choice of address terms signals the relationship between language and the society and how a person imagines his/her relationship with the addressee within this society. Address terms, therefore, provide sociolinguistic information about the the interlocutors as well as pragmatic aspects of the situation (Oscan, 2016:982). This indicates that sociopragmatic approach can be used to analyze the use of address terms in society's daily life. Not only are the address terms used in the society considered, 
but the relationship among their users should also be taken into account.

Javanese culture is a part of Indonesian culture. Javanese inhabitants live in many parts of archipelagic areas of Indonesia. They spread to most areas or islands of Indonesia. This fact makes the Javanese culture also spread to those areas, and thus influence the Indonesian culture. In other words, Javanese and Indonesian cultures are interrelated. In some cases, Indonesian cultures may absorb Javanese cultures. In contrast, Javanese people may automatically apply Indonesian cultures. This phenomenon also occurs in the use of address terms in various aspects of Indonesian people's life. However, in Javanese culture although just expressing using address terms, the motivation to express them should not threaten someone's feeling (Wierzbicka, 2003: 128). English cultures have no a significant difference in the use of address terms from Javanese and Indonesian cultures. English people address others in various ways regarding whom they talk to, when they talk, etc.

There are many factors which can lead to the appropriate choice of address terms by the users. The factors may derive from various aspects. Wardhaugh (2006:272) states the use of address terms is influenced by many social factors. These various factors are identical to the complexities of using address terms in different cultures. In addition, a person may misuse an address term because of his unfamiliarity with the interlocutors or addressees. If it so happens, the communication will not run smoothly. Therefore, the speaker's familiarity with the addressee in many aspects is an important factor to keep the verbal interaction run well and more politely.

Situational contexts can also influence the use and choice of address terms. Different situations call for different address terms. A person may be addressed with various address terms just because of different situations. A son or daughter may call his or her father differenly when they are at home and in the office. This indicates that formal and informal situations bring about the different use of address terms. They are more variously used in informal situations than in formal situations.

\section{Theoretical Review}

Language and culture are very closely related. Sapir (1949:207) states "language does not exist apart from culture, that is, from the socially inherited assemblege of practices and beliefs that determines the texture of our lives". Culture is shared beliefs, values and behaviors of a social group, where social group can be a family at a micro level and a nation at a macro level. Culture refers to a set of practices, codes, and values which indicate a community (Morgan, 1999: 495; Farr dan Ball, 1999: 206 as cited in Gunarwan, 2007: 57). One of the ties between language and culture is that ideas, customs, beliefs, morals, codes, and traditions are typically passed on through talking.

Addressing is a universal phenomenon and different cultures call for different language forms. This idea is in line with what is said by Samavor, Porter, and Stefani (2011 as cited by Yu and Ren, 2013:38) who explain that language and culture are intertwined, that is, in broad sense culture permeates every aspect of the society; and language is shaped and conditioned by culture. Furthermore, the power of language to reflect culture and influence thinking was first proposed by Edward Sapir and his student, Benjamin Whorf. The Sapir-Whorf hypothesis or Worfian hypothesis states that the way we think and view the world is determined by our language. Citing Sapir (1929), Wardhaugh (1992:218) explains that language and culture are inextricably related. The cultural norms which are reflected from speech acts vary not only from language to language, but also from one social and regional variety to another in one culture (Wierzbicka, 2003).Wierzbicka (1991 as cited in Eshreteh, 2015:1) has pointed out that speech acts reflect fundamental cultural values that may be specific to a speech community. Cultures have been shown to vary drastically in their interactional styles, leading to different preferences for modes of speech act behaviours.

Sociopragmatics is the aspect of language use that relates to everyday social practices. The term 'sociopragmatics' was coined by Leech (1983: 10) to describe the ways in which pragmatic meanings reflect 'specific "local" conditions on language use'. Sociopragmatics focuses on language use (pragmatics) not language usage in society (sociolinguistics) with certain cultural and social contexts (see Rahardi, 2009:4). Leech (1983 cited by Ali, 2018) defines sociopragmatics as the use of linguistic aspects in relation to social context; that is, using utterances with regard to social factors (power, distance, imposition, etc.) in a particular context.

An address term is a word, phrase, name, or title (or some combination of these) used in addressing someone in writing or in speech. According to Fasold (1990 as cited by Ozcan, 2016) address forms are the words speakers use to designate the person they are talking to while they are talking to them. A term of 
address may be friendly, unfriendly, or neutral; respectful, disrespectful, or comradely. Wardhaugh (2006:272) states the use of address terms is influenced by social states, gender, age, family relationship, occupational hierarchy, race, and the degree of intimacy. Meanwhile, Yang (2010) explains that "how to address people needs the taking of several factors into consideration, such as the social status or rank of the others, sex, age, family relationship, occupational hierarchy, transactional status, race, or degree of intimacy".

The use of address terms must be suitable with the habits of the local culture, politeness habits, and the conversational situations. Each group of community, even each family, has its own culture in applying address terms system. Javanese, Indonesian, and English people use address terms with their own cultures in different complexities. The culture of using address terms can be distinguished socially and geographically. The address terms used by the upper social class are different from those of lower social class. The group of society living in one region has different systems of address terms from the one living in another region.

\section{Methodology of the study}

This study belongs to descriptive qualitative type because the data were not in numbers but in words, phrases, or utterances and there was no a statistical procedure. This study aims to describe the natural phenomena of using address terms in daily life. The research object was address terms and the research subjects were the Javanese and Indonesian people and the written sources in the forms of English books and electronic sources. This study was mainly conducted in Javanese cultures as a part of Indonesian cultures and compared with English cultures. In this analysis, the culture in terms of which the address terms were used was Javanese culture with some subcultures. In English and Indonesian cultures, the address terms were analyzed as a comparison with Javanese cultures. The data were the expressions or utterances containing address terms in Javanese, Indonesian, and English. The data of Javanese and Indonesian address terms were collected from the daily life and those of English were collected from written and electronic sources. The data were collected by using observation method, noting technique, and intuition technique. Then, the collected data were analyzed by using padan pragmatik method, comparison method, and agih method for certain cases (Sudaryanto, 2015).
Finding and Discussion

A. Types of address terms in different cultures

\begin{tabular}{|c|c|c|c|c|}
\hline No & $\begin{array}{c}\text { Types of } \\
\text { Address } \\
\text { Terms }\end{array}$ & Javanese & Indonesian & English \\
\hline 1 & $\begin{array}{l}\text { Kinship } \\
\text { terms }\end{array}$ & $\begin{array}{l}\text { Mamak, } \\
\text { Pakdhe, } \\
\text { Dhuk. } \\
\text { Eyang }\end{array}$ & $\begin{array}{l}\text { Ibu, Paman, } \\
\text { Kak, Kakek }\end{array}$ & $\begin{array}{l}\text { Mummy, } \\
\text { Uncle, } \\
\text { Brother, } \\
\text { Granpa }\end{array}$ \\
\hline 2 & $\begin{array}{l}\text { Title or } \\
\text { occupation } \\
\text { names }\end{array}$ & $\begin{array}{l}\text { Lurah, } \\
\text { Bupati, } \\
\text { Dokter, } \\
\text { Suster } \\
\end{array}$ & $\begin{array}{l}\text { Kades, } \\
\text { Jenderal, } \\
\text { Dokter, } \\
\text { Suster } \\
\end{array}$ & $\begin{array}{l}\text { Prof, } \\
\text { Commander } \\
\text {, General, } \\
\text { Captain }\end{array}$ \\
\hline 3 & $\begin{array}{l}\text { Names of } \\
\text { persons }\end{array}$ & $\begin{array}{l}\text { Suharto, } \\
\text { Bejo, } \\
\text { Paiman, } \\
\text { Kliwon }\end{array}$ & $\begin{array}{l}\text { Abdul, Ida, } \\
\text { Siti, Ani, } \\
\text { Rosyadi }\end{array}$ & $\begin{array}{l}\text { Smith, } \\
\text { George, } \\
\text { Alice, John }\end{array}$ \\
\hline 4 & $\begin{array}{l}\text { Naming } \\
\text { terms }\end{array}$ & $\begin{array}{l}\text { Den, Ndara, } \\
\text { Gusti }\end{array}$ & $\begin{array}{l}\text { Tuan, } \\
\text { Nyonya, } \\
\text { Tuhan, } \\
\text { Sayang } \\
\end{array}$ & $\begin{array}{l}\text { Boss, God, } \\
\text { gods }\end{array}$ \\
\hline 5 & $\begin{array}{l}\text { Terms of } \\
\text { acting } \\
\text { persons }\end{array}$ & $\begin{array}{l}\text { Pamirsa, } \\
\text { Pambiwara }\end{array}$ & $\begin{array}{l}\text { Penonton, } \\
\text { Pendengar, } \\
\text { Hadirin } \\
\end{array}$ & $\begin{array}{l}\text { Participants, } \\
\text { Presenters }\end{array}$ \\
\hline 6 & $\begin{array}{l}\text { Terms of } \\
\text { personal } \\
\text { pronouns }\end{array}$ & $\begin{array}{l}\text { Sampeyan, } \\
\text { Dheweke }\end{array}$ & $\begin{array}{l}\text { Anda, } \\
\text { Saudara, } \\
\text { Dia, Mereka }\end{array}$ & $\begin{array}{l}\text { You, They, } \\
\text { He, She }\end{array}$ \\
\hline 7 & $\begin{array}{l}\text { Respecting } \\
\text { terms }\end{array}$ & $\begin{array}{l}\text { Pepundhen, } \\
\text { Pini Sepuh }\end{array}$ & $\begin{array}{l}\text { Paduka, } \\
\text { Yang Mulia }\end{array}$ & $\begin{array}{l}\text { Sir, Lady, } \\
\text { Lord }\end{array}$ \\
\hline 8 & $\begin{array}{l}\text { Combinatio } \\
\text { ns of } \\
\text { address } \\
\text { terms }\end{array}$ & $\begin{array}{l}\text { Pakdhe } \\
\text { Harto, } \\
\text { Eyang } \\
\text { Radji, Mbok } \\
\text { Sarto }\end{array}$ & $\begin{array}{l}\text { Ibu } \\
\text { Winarni, } \\
\text { Paman } \\
\text { Barkah, } \\
\text { Saudara } \\
\text { Hasan } \\
\end{array}$ & $\begin{array}{l}\text { Uncle Tom, } \\
\text { Brother } \\
\text { John, Mr. } \\
\text { Brian }\end{array}$ \\
\hline
\end{tabular}

It can be seen from the table above that there are many types of address terms in each culture, especially in Javanese, Indonesian, and English cultures. Even, those address terms are more various if they are analyzed in detail in terms of subcultures either in family life or in public life and either in formal or informal situations. The examples unequally given in the table are just a few data which can actually be found in a lot of numbers in those cultures.

\section{B. Address Terms in Family Life}

A family is the smallest unit of societal organization which consists of a father, a mother, children, and other possible members living in a house. A family is a place where the members living in can think, plan, and realize their life goal. As a social group, a family comprises some related and united individuals having different responsibility. It also serves as a place where its members share their own experience, interact among the others, and create and keep a culture. One of the cultures is addressing one another using 
address terms in a family life. Different families apply different address terms. The different uses of address terms described in this part are based on different cultures which are influenced by social class factors of the users and the regions in which the cultures apply disregarding the culture in the Sultan Palace. The following is the discussion of address terms uses in Javanese (sub)cultural family lives compared with other cultures.

\section{Address terms used by husband and wife}

As members of a family, a husband and a wife control the life of their family. Hence, they have to be able to be a good role model for their children. One thing which they can do is using proper address terms between them. Address terms between a husband and a wife from one family to the others are differently used depending on their habits and other social factors such as education and religion. In Javanese cultures, the possible address terms used by a husband and a wife already having children are bapak-ibu (pak-bu), pakne-bune, pakmu-ibumu, ayah-ibu (yah-bu), papa-mama (pa-ma), papi-mami (pi-mi), abi-umi, etc. Those who have no children yet, the address terms used are different, such as (sa)yang, mas-dik, or using names. Formerly, the use of address terms tended to be unvarious because they still obeyed the customs. The address terms used by a husband and a wife belonging to different social class are different. Those coming from lower social class commonly use pakne-bune or bapakmu-ibuти (ракти-ibuти), as seen in the following examples.

(1) Bune, lawang pawon ditutup dhisik. Ma, please close the kitchen door'

(2) Pakmu, Pak Harto jarene arep mantu, suk dina Minggu ngarep iki.

Pa, Mr. Harto will celebrate his daughter' wedding next Sunday.

Meanwhile, other address terms such as papa-mama, papi-mami, abi-umi, and ayah-ibu are commonly used by middle and upper social class couples who are more modern due to their education or religion knowledge. The address term papa-mama derives from English father-mother which demands the knowledge or education by its users. The same is true for ayah-ibu. Although this address term is more neutral or general, the term ayah is not commonly used by Javanese couples. They are more familiar with bapak instead of ayah, thus requiring a specific understanding on ayah. The following are the examples.
(3) Suami : Ma, mrenea dhisik. Aku arep ngomong. 'Ma, come here. I'll tell you'

Isteri : Ana apa, Pa? Kok sajak penting banget. 'What's wrong, Pa? It seems to be very important'

(4) Isteri : Ayah sesuk Minggu tindakan ora? Arep takkon ngeterke aku. 'Will Papa go next Sunday? I'll ask you to take me to'

Suami : Arep lunga neng endi, Bu? 'Where do you want to go, Mom?'

The utterance (3) is impossibly used by the Javenese poor families, except they come from Sundanese. Meanwhile, the utterance (4) may be used by limited Javanese poor families, except the term ayah which is commonly used by husband and wife belonging to minddle and upper social class.

Another phenomenon is the use of abi-umi (bi-mi). This address term is specially used by Javanese couples adhering strickly to Islam religion as their background knowledge and adopting it from Arabic culture. Islamic terms are identical to Arabic. This influences those who strickly adhere to Islam to adopt Arabic cultures including in the use of address terms. It implies peaceful feelings in the users. The examples that follow prove the phenomenon when a husband asked his wife to be in a hurry to go to the mosque.

(5) Husband : Ayo cekat-ceket, Mi. selak qomat kae. 'Hurry up, Mom. Iqomah will sound soon'

Wife : Iya, Bi. Iki lagi nggoleki mukena. 'Yes, Pa. I'm looking for my veil'

The general address terms used by Javanese couples are bapak-ibu (pak-bu) as the following examples show.

(6) Wife : Pak, Pak! Mrenea, Pak. Tulungana iki. Abot je. 'Pa, Pa! Come here, Pa. Help me. It's heavy.

Husband: $Y a$, sik, Bu. Iki lagi nanggung. 'A moment, Ma. I'm still working'

(7) Wife : Bapak wingi rapat $R T$ ngrembug pitulasan. Bener, Pak? 'Papa discussed Independence Day programs. Did you, Pa? 
Husband: Pak RT ngersakake Ibu(k) dadi bendahara panitia. Piye, Bu? 'Mr. RT asked you to be the committee treasurer. What do you think, Ma?'

It can be understood by Javanese society that the utterances (6) dan (7) can be used by husband and wife from all social backgrounds. However, the more modern or developed couples in certain aspects tend to use the utterances (3) - (5) instead of (6) dan (7).

The various uses of address terms used by Javanese couples above are not found in English cultures, except the utterance (3). In addition, English couples commonly use papa-mama (pa-ma/pa-mom or other intimate address terms such as honey and sweety as shown in this example.

(8) Husband : Hi, Sweety. What we have for dinner. What about dinner out?

Wife : Abasolutely agree, Honey.

The address terms sweety and honey are used to show intimacy between a husband and a wife in English cultures. This may happen to couples coming from all social backgrounds.

\section{Address terms used by children and their parents}

Some address terms used by the Javanese couples explained above are also used by the children when addressing their parents, for instance bapak-ibu and papa-mama. The address terms bapak-ibu are more general, that is, the children coming from all social backgrounds may use them. Meanwhile, papa-mama are more specific, meaning that they tend to be used by the children coming from middle and upper social classes with specific backgrounds. In contast, the children coming from lower social classes tend to use bapak-simbok (pak-mbok) or bapak-mamak (pak-mak) and the like to address their parents.

The cultures of villagers living in rural areas and coming from lower social classes are traditional and hereditery including in the use of address terms. To address their sons, they use the address term le (thole) and ndhuk (gendhuk) for their daughters. Meanwhile, in addressing their parents, the children use bapak or pak for their father and simbok or mbok for their mother as the following examples show.

(9) Mother: Ndhuk, sinaune sing sregep ya. 'My daughter, please study hard'

Daugher : Ya, mbok. 'Yes, Mom.'

(10) Father : Ayo neng sawah, ngrewangi bapak, Le. 'Let's go to the rice field, helping me, my son.
Son Dad.' : Mengko dhisik, Pak. 'Wait a moment,

The utterances (9) and (10) reflect the culture of lower social class Javanese society in using address terms between children and their parents. The address terms ndhuk and le are exotic enough because the users come from lower social class, uneducated families that usually live in rural areas. This habit is inherited to the chidren when they become parents in the notes that they still belong to the same level of social class. It so happens because the culture does not demad to replace the address terms. The traditional life of the society coming from lower social class just continues and results from the previous traditions or habits.

On the other hand, the families coming from middle and upper social classes apply modern, not traditional, cultures due to various factors. For the sake of modernization, they imitate the more developed families' lives so that they do not use the utterances (9) dan (10). To address their children, the parents use dhik or his/her names. In contast, the children address their father using bapak, papa, abi or ayah and their mother using ibu, mama, or umi. Here are the examples.

(11) Son (Roni) : Papa, minta duit, Pa. buat beli bensin. 'Papa, can I get some money, Pa? I want to buy some gasoline'

Papa : Kan durung suwe ta, Ron, sing tuku. Kok wis njaluk maneh. 'You've just bought it, Ron. Why do you ask for it again?'

(12) Mama : Dhik, Dhik, aja nengah-nengah, rada minggir mlakune. 'My boy, don't run through the middle. Come to the edge'

Child : Dalane sepi kok, Ma. 'No traffic jam, Ma'

(13) Child : Umi, sing ngeterke les nanti sore, sapa Mi? 'Mummy, who will take me to the extracurricular program this afternoon, Mom?'

Ibu : Umi nanti sore ana acara PKK, nanti ben diterke abi atau masmu wae. 'This afternoon, I have PKK program, your daddy or your brother will take you there'

From the utterances (11) - (13) above, it can be understood that the Javanese famililies' lives have got 
the influence from the external cultures in terms of the experiences which are different from the traditional families. They may get such experiences as higher education, education in Islamic boarding schools, or other culturally external experiences. In Javanese context, specifically in Yogyakarta and Surakarta regions and in the sorrounding regions, there are almost no papa-mama address terms which are used by the poor families living in villages. It is also difficult to find children addressing their parents using them, although coming from middle and upper social classes, and using abi-umi when they have very less understanding on Islam and no strickly adhering to it.

In English cultures, when addressing their parents, the children use Dad-Mum or Daddy-Mummy address terms. These two varieties are used differently in terms of the age difference, but there is no a clear-cut. To address their parents, the teenagers and youths commonly use Dad-Mum, while the children commonly use Daddy-Mummy. Daddy-mummy are firstly used by children in their childhood. Then, the change from daddy-mummy to dad-mum occurs when the children already grow to teenagers onwards. But, the age border is not rigid. A three-year child may address his father using Dad just because he often hears it from teenagers. The following are the examples in Indonesian and English cultures.

(14) Father : Rina, kapan UTS di sekolahmu?

'Rina, when will your mid- term exam in your school be held?

Daughter : Memangnya ada apa, Yah? 'What's happening, Dad?

(15) Daughter : Why does Mom wear make up?

Father : To look pretty.

Daughter: But she's already pretty.

Father : Aww.

Daughter : Dad, you should wear make up.

(16) Son : Mummy, Daddy, I'm leaving.

Mother : Yeah, take care, Bob.

Father : Is nothing left, Bob?

C. Address terms in public life

The address terms used in public life are not as complex as in family life. They can be divided into some kinds, namely address terms between the youths (including children from external families) and old people, addres terms among the youths, and address terms among colleagues. In Javanese cultures, in addressing old people (not grandfather and grandmother), the youths commonly use generic or neutral address terms such as bapak (pak) and ibu (bu). Meanwhile, the old people tend to use mas-mbak, dhik(adhik), nak, names of persons, or the combination of address terms and the names. Those address terms are used by old people from all social classes disregarding the subcultures, except the term nak. Traditionally, this term is used by those who belong to lower social class or are inherited from it. The following are the examples.

(16) Youth : Ngapunten, Bu. Napa leres niki griyane pak Sarto?

'Excuse me, Mom. Is this Mr. Sarto's house?'

Woman : Nggih, leres Nak. Mangga pinarak, Nak.

'Yes, you're right, Boy. Come in, Boy.'

(18) Youth : Matur nuwun, Bapak, atas bantuannya. 'Thanks for helping, Sir.

Man : Sama-sama, Dhik. 'You're welcome, Boy'

(19) Woman : Mbak Sita sudah matur ibu, jadi ikut piknik tidak? 'Sister Sita, have you told your mother? Does she happen to join the excursion?

Girl (Sita): Sampun, Bu. Jadi ikut, Bu. 'I"ve done, Mom. She will join, Mom'

Another phenomenon happens to the youths. The intimate youths use names, nick names, or their combination with the terms mas-mbak, while the youths unknown each other usually use mas-mbak. The use of those address terms is not influenced by the subcultures which attach to them. Even, their use of address terms changes according to the era development, for instance, the use of bro (brother) borrowing from English. Due to the mere imitation, the address terms are sometimes redudantly used, like mas bro, whereas the two terms have the same meaning. How the youths address one another can be seen in these examples.

(20) Antin: Tut, Mas Joko sudah dikasih undangan kumpulan pemuda belum? 'Tut, has Brother Joko been invited to the youth meeting?'

Tuti : Wis ditulis kae, Mbak. Cuma belum diterke wae. 'His name has been on the envelope, Sister. It's not been sent yet' 
(21) Male Youth : Maaf, Mbak. mau tanya, desa Kebondalem Kidul, sebelah pundi, Mbak? 'Excuse me, Sister. Where's Kebondalem Kidul village, Sister?'

Female Youth: Mase, saking pundi? Itu jalan raya tadi, Mase lurus ke selatan, perempatan jalan ada bangjo, terus saja, sampai rel kereta api. Kidul rel itu desa Kebondalem Kidul.

'Brother, where do you come from? On the main road, you go straight to the south until you find a crossroad with traffic light, then go ahead until finding a railway. Kebondalem Kidul is after the railway'

It is understood that the utterance (20) is uttered by two intimate female youths in a youth meeting, while the utterance (21) is uttered by a male youth and a female youth who have not known each other.

Other address terms appear among colleagues in a workplace. The workplaces -government or private offices, schools, higher educations- demand formal activities. Therefore, the generic address terms, such as bapak-ibu, are preferably used by the colleagues to address one another. No variety of address term is used in this context. When there are other address terms, for instance mas-mbak or the combination of mas-mbak and names of person, they possibly appear due to certain factors. The following are the examples of using address terms in a meeting.

(22) Meeting leader : Bapak-bapak, Ibu-ibu yang saya hormati, marilah rapat siang ini kita awali dengan membaca lafadz "basmallah".

'Everyone, let's open this meeting by reciting basmallah'

The generic address terms bapak-bapak and ibu-ibu are not only found formally in a workplace but also informally. This so happens because a workplace is assumed to be formal. When other address terms, such as mas-mbak, appear in a workplace, there may be two possibilities. One is meant to show the intimacy, and the other is intended to show the speaker's ego as a senior clerk. These examples are used in Javanese and Indonesian cultures.

(23)Clerk A: Ibu sudah mendengar berita tentang perpanjangan usia pensiun bagi PNS? 'Mom, have you heard the news on pension lengthening for civil servants?

Clerk B : Sudah, Pak. Yang diperpanjang pensiunnya kan hanya pegawai kantor. Kita yang guru ya tetap sama. 'I have, Sir. The lengthening
Is valid for office staffs. For teachers, it's still the same.

(24) Senior clerk : Mas Burhan ngawas ujian tidak hari ini? 'Burhan, do you Supervise the exam today?

Junior clerk : Ya, Bapak. 'Yes, Sir'

(25) Clerk A : Mbak Nur, ada tawaran penelitian lagi. Ayo ngajukan lagi.

Sister Nur, there is a research offer again. Let's propose'

Clerk B : Ya, Bu. Bagaimana kalau berkelompok? 'Yes, Mom. How about doing it in a group?'

The utterance (23) is uttered by two goverment teachers who talked about the lengthening age of pension. The address terms used are the generic ones, namely bapak-ibu or pak-bu. Then, the utterances (24) dan (25) contain uncommon address terms mas-mbak since it happens in a formal workplace. The utterance (24) is uttered by two lecturers who are different in seniority. The senior lecturer intends to show his ego and addresses his junior by using mas. Meanwhile, the utterance (25) is also uttered by two lecturers but no seniority is showed. The use of mbak plus a name (Mbak Nur) is just to show their intimacy or equality. In English cultures, these utterances serve as the examples to show similar cases.

(26) They're magicians, your honor. Men who live by dressing up plain and simple truths to shock, to amaze.

(27) If you've got thin soup, then that's your supper.

Sorry, mate. That's the way it is.

\section{Factors of using address terms}

The use of address terms is much influenced by many factors. People in every culture use the address terms based on various social backgrounds. The following is the short discussion of the factors influencing the people in using address terms di different cultures.

1. Different kinship

Javanese, Indonesian, and English cultures have different address terms in terms of different kinship. Javanese people have bulik, pakdhe; Indonesians have paman, bibi; and English people have uncle, aunt.

2. Age difference

The nonreciprocal use of mbak/mas by seniors to address the juniors, and the use of 
bapak/Ibu by juniors to address the seniors indicate that there is an age difference. Those address terms can be used in Javanese and Indonesian cultures. Other terms which can be used are the nonreciprocal use of $(a) d h i k$ vs mas/mbak.

3. Education

Because of the higher educational factor, people may be addressed by public or people having lower education using dokter, suster, profesor in Javanese and Indonesian cultures and professor, doctor in English cultures.

4. (Islam) religion knowledge

These address terms Umi, Abi, Anta, Anti, Antum are used by specific community or families adhering stickly to Islam. These address terms require the users to have sufficient knowledge of Islam religion. Of course, the terms are borrowed from Arabic (Qur'an language) because Islam is inherited from Saudi Arabia.

5. Sex

In every culture, males and females are addressed differenly including in Javanese, Indonesian, and English cultures. In Javanese, for instance, ndhuk, bu are used to address females and thole, pak to address males. In Indonesian, tuan, bapak are used to address males and nyonya, $i b u$ to address females. Meanwhile, in English, brother, dad, sir, mr. are used to address males and sister and mum, ms, mrs. to address females.

6. Different job accupation/position

Pak Lurah, Pak Kades, Pak Dekan, Pak Menteri, and Mr. President, Captain are respectively used address terms in Javanese, Indonesian, and English cultures. Those address terms can be used by public or the people having different job occupation or position.

7. (Different) intimacy

A different intimacy calls for different address terms. The nonreciprocal use of address terms described above indicates this point. To show the intimacy, the following address terms are used: bune, pakne, (nick)names of person in Javanese cultures; kawan, sobat, (sa)yang in Indonesian cultures; and guys, mate, my sweetheart, my love in English cultures.

8. Social class / status

The people belonging to different social class or status use different address terms. It reflects the nonreciprocal relationship. The Javanese address terms den and ndara are used by lower class people (servants, beggers) to address their upper class (employer, boss). The same is true for tuan and nyonya in Indonesian, and Sir and Mr. John in English.

9. Geographical group

Geographical group is identical to regional dialect. Javanese has some regional dialects which can be realized in the use of address terms. The terms jeng, nimas, dhimas are used in central Javanese cultures, namely Yogyakarta and Surakarta; bapake, mboke are used in Banyumas Javanese cultures; and koen, Pak Puh are used in east Java Javanese cultures, especially in Surabaya. Lu, ente are used in Betawi (Jakarta) and kamu, anda, kau in other parts of Indonesia

\section{Conclusion}

There are a lot of address terms which are used very variously in Javanese, Indonesian, and English cultures. Regarding the characteristics of the address terms users, in family life, there are many specific address terms, while in public life, there are many generic address terms. In certain cases, there is no a clear cut of the use of the address terms in family life and in public life. Some address terms are used both in family life and in public life. In Indonesian context, some address terms can be used in Javanese and Indonesian cultures. Among the factors influencing the use of the address terms are (1) different kinship, (2) age, (3) education, (4) (Islam) religion knowledge, (5) sex, (6) different job accupation/position, (7) (different) intimacy, (8) social class, and (9) geographical group. Address terms are also used formally and informally.

\section{References}

Ali, S. A. (2018). Socio-pragmatic deficiency in e.eequests. IRA International Journal of Education and Multidisciplinary Studies. Vol. 10, Issue 03, March 2018, pp. 26 - 34.

Eshreteh, M. K.M. (2015). Re-assessing cross-cultural [ragmatics: Insistence as a marker of affiliation and connectedness". Cross Cultural Communication. Volume 11, No 1, 2015, pp 1-7.

Gunarwan, A. (2007). Pragmatik: Teori dan Kajian Nusantara. Jakarta: Penerbit Universitas Atma Jaya.

Leech, G. 1983. Principles of Pragmatics. London: Longman.

Oscan, F. H. 2016. "Choice of Address Terms in Conversational Setting". International Journal of Human Science. Volume 13. Issue 1. 
Rahardi, Kunjana. 2009. Sosiopragmatik. Jakarta: Penerbit Erlangga.

Sapir, Edward. 1949. Language. New York: Harcourt, Brace, \& World, Inc.

Wardhauh, Ronald. 1992. Introduction to Sociolinguistics. $2^{\text {nd }}$ edition. Oxford: Blackwell Publishers.

Wardhauh, R. (2006). Introduction to Sociolinguistics. $5^{\text {th }}$ edition. Oxford: Blackwell Publishing Ltd.

Wierzbicka, Anna. 2003. Cross-Cultural Pragmatics. Berlin: Mouten de Gruyter.

Yang, Xiaomei. 2010. "Address forms of English: Rules and Variations". Journal of Language Teaching and Research. Vol. 1, No. 5, pp. 743-745, September 2010.

Yu, Hao and Chi Ren. 2013. "A Comparative Study of Social Address Terms in Chinese and English".
Higher Education and Social Science. Volume 5, No 3, 2013, pp. 35 - 40.

badanbahasa.kemdikbud.go.id/lamanbahasa/petunjuk praktis/495/Kata\%20 Sapaan (retrieved on January 10, 2018)

Blake, Barry J. 2008 .All About Language. Oxford: Oxford University Press (in grammar.about.com/od/tz/g/termofaddresste rm.htm. (retrieved on January 10, 2018) grammar.about.com/od/tz/g/termofaddressterm.htm (retrieved on January 10, 2018).

www.netmums.com/coffeehouse/general-coffeehousechat-514/coffee-lounge-18/593311-daddy-dad-all.html, (retrieved on January 10, 2018). 